\title{
Bovine Ephemeral Fever (BEF) : Penyebab, Epidemiologi, Diagnosa, dan Terapi
}

\section{Bovine Ephemeral Fever (BEF): Causes, Epidemiology, Diagnosis, and Therapy}

\author{
Alfarisa Nururrozi, Soedarmanto Indarjulianto, *Yanuartono, Hary Purnamaningsih, \\ Slamet Rahardjo, dan Rusmihayati

\begin{abstract}
Departemen Ilmu Penyakit Dalam, Fakultas Kedokteran Hewan Universitas Gadjah Mada. Jl. Fauna No.2, Karangmalang, Depok, Sleman. 55281 Yogyakarta. Tel: +62-274-560862, Fax +62-274-560861

*Email: yanuartono20@yahoo.com
\end{abstract}

Naskah diterima: 14 Desember 2018, direvisi: 22 April 2019, disetujui: 30 Maret 2020

\begin{abstract}
Bovine ephemeral fever (or 3-day sickness) is an acute febrile illness of cattle and water buffaloes caused by an Ephemerovirus of the family rhabdoviridae. The disease transmitted by arthropod vectors. It is common in tropical and subtropical regions. The main impact of BEF infection cause decreased productivity, decreased milk yield, body score and reproductive losses, and recovery can be prolonged in some animals. Clinical signs vary in individual animals, but the classic course begins with a fever, which is often biphasic to polyphasic. Mortality is typically low, however, significantly higher case fatality rates were reported in some recent outbreaks. This disease is widespread in various regions in Indonesia. In general, BEF does not cause large economic losses if medical assistance is provided sufficiently so that complications do not occur with other diseases. This paper aims to summarize the causes, epidemiology, diagnosis methods, and treatments that can be done to overcome BEF disease.
\end{abstract}

Key words: Bovine ephemeral fever; arthropod vector; clinical signs; outbreaks.

\begin{abstract}
Abstrak
Bovine ephemeral fever (atau 3-day sickness) adalah penyakit demam akut pada sapi dan kerbau yang disebabkan oleh Ephemerovirus dari keluarga rhabdoviridae dan ditularkan oleh vektor arthropoda. Penyakit tersebut biasa terjadi di daerah tropis dan subtropis. Efek infeksi BEF pada ternak adalah penurunan produktivitas, produksi susu, kondisi tubuh, gangguan reproduksi, dan periode pemulihan yang lama pada beberapa hewan. Gejala klinis bervariasi pada setiap individu hewan, tetapi pada umumnya diawali dengan demam yang bersifat bifasik melanjut menjadi polifasik. Mortalitas biasanya rendah, namun, peningkatan kasus berakibat fatal telah dilaporkan dalam beberapa wabah akhir-akhir ini. Penyakit ini tersebar luas diberbagai daerah di Indonesia. Secara umum tidak menimbulkan kerugian ekonomi yang besar, asalkan segera mendapatkan pertolongan medis yang memadai sehingga tidak terjadi komplikasi dengan penyakit lain. Tulisan ini bertujuan untuk mengulas penyebab, metode diagnosa, dan terapi yang dapat dilakukan untuk menanggulangi kejadian BEF.
\end{abstract}

Kata kunci: Bovine ephemeral fever; vektor arthropoda; gejala klinis; wabah.

\section{Pendahuluan}

Bovine ephemeral fever disebabkan oleh virus RNA beruntai tunggal (ssRNA) sense-negatif, genus Ephemerovirus, famili Rhabdoviridae (Walker, 2005; Strauss and Strauss, 2008; Walker and Klement, 2015). Penyakit BEF sering juga disebut 'three days sickness', stiff sickness, dengue fever of cattle, bovine epizootic fever dan lazy man's disease (Kirkland, 2016). Penyakit BEF pertama kali ditemukan tahun 1867 pada sapi di Afrika Tengah, setelah itu ditemukan di Afrika, Asia, dan Australia (Trinidad et al., 2014). 
Laporan kejadian BEF di Indonesia, diduga pertama kali terjadi pada tahun 1920 di Sumatera dan pada tahun 1979 penyakit yang sama muncul kembali pada sapi ongole di Tuban dan Lamongan, Jawa Timur (Soeharsono et al., 1983). Kasus BEF banyak terjadi di beberapa daerah beriklim tropis, subtropis dan panas di Afrika, Australia, Timur Tengah dan Asia (St George and Standfast, 1988). Sampai saat ini diketahui hanya sapi dan kerbau yang dapat terinfeksi virus BEF (Walker et al., 1991; Aziz-Boaron et al., 2012; Momtaz et al., 2012). Meskipun tidak menunjukkan gejala klinis, antibodi terhadap virus BEF juga terdeteksi pada banyak hewan liar seperti termasuk kerbau Afrika (Syncerus caffer), hartebeest (Alcelaphalus buselaphus), waterbuck (Kobus ellipsiprymnus), wildebeest (Connochaetes taurinus), kudu (Tragelaphus strepsiceros), jerapah (Giraffa camelopardalis), gajah (Loxodonta africana), kuda nil (Hippopotamus amphibius), babi hutan (Phacochoerus aethiopicus) dan berbagai spesies rusa dan antelop (Davies et al., 1975; Barnard, 1997; Anderson and Rowe, 1998; Hamblin, 2008; Aziz-Boaron et al., 2015).

Virus BEF diduga ditularkan oleh arthropoda meskipun vektor yang terlibat tidak sepenuhnya jelas (Walker and Klement, 2015). Virus tersebut telah berhasil diisolasi dari berbagai genera nyamuk dan dari sejumlah spesies culicoides (Kay et al., 1975; Murray, 1997). Bukti epidemiologi dan pemeriksaan laboratorium dari beberapa lokasi menunjukkan bahwa nyamuk adalah vektor biologis primer. Namun, ada beberapa indikasi bahwa culicoides mungkin merupakan vektor yang signifikan di beberapa bagian benua Afrika (Bai et al., 1991; Ogawa, 1992). Transmisi penularan dari vektor terinfeksi melalui angin diduga telah menjadi penyebab wabah di beberapa wilayah seperti Australia dan Jepang (Finlaison et al., 2010; Hayama et al., 2016). Lebih lanjut menurut Mellor et al., (2000), kondisi lingkungan dan iklim di daerah setempat mempengaruhi habitat vektor dan mempengaruhi penyebaran penyakit tersebut.

Gejala klinis BEF kemungkinan bervariasi pada setiap individu hewan, tetapi biasanya dimulai dengan demam bersifat biphasic dan puncak suhu tubuh biasanya terjadi 12 hingga 18 jam. Produksi susu sering turun secara drastis selama puncak demam pertama dan pada saat tersebut, gejala klinis lain mungkin tidak teramati, meskipun beberapa hewan mungkin mengalami depresi, kaku atau malas untuk bergerak (Hsieh et al., 2005; Tonbak et al., 2013). Gejala kaku dan malas bergerak memiliki kemiripan pada kasus footrot disease (Budhi et al., 2007). Tingkat mortalitas penyakit BEF biasanya rendah (1-2\%) terutama pada sapi dengan kondisi sehat, namun demikian mortalitas dapat meningkat sampai $30 \%$ pada sapi dengan kondisi gemuk dan tingkat morbiditas dapat mencapai $80 \%$ jika terjadi wabah $\mathrm{BEF}$ (Roya, 2008; Zheng et al., 2011; Momtaz et al., 2012). Manifestasi klinis yang berat dan kerugian ekonomi yang besar akibat BEF pada tahun tahun terakhir menyadarkan para peternak dan industri peternakan untuk lebih memberikan perhatian pada epidemiologi, cara penularan, pencegahan dan pengendalian $\mathrm{BEF}$ untuk menghindari kerugian ekonomi yang jauh lebih besar (Zaghawa, 2006). Terapi BEF biasanya menggunakan anti radang ditambah dengan kalsium boroglukonat jika muncul gejala hipokalsemia seperti stasis rumen, paresis serta hilangnya refleks tubuh (Yeruham et al., 2010). Pengobatan antibiotika dapat diberikan untuk mengontrol infeksi sekunder dan rehidrasi dengan cairan isotonik (St George, 1988). Tulisan ini bertujuan untuk memberikan tinjauan pustaka secara singkat penyebab, penyebaran, metode diagnosa dan terapi yang dapat dilakukan untuk menanggulangi kejadian BEF.

\section{Penyebab dan Penularan BEF}

Bovine ephemeral fever (BEF) adalah penyakit viral yang ditularkan oleh serangga (arthropod borne virus), termasuk dalam famili Rhabdoviridae dan genus Ephemerovirus. Bovine ephemeral fever disebabkan oleh virus Double Stranded Ribonucleic Acid (ds-RNA), memiliki amplop dan berbentuk peluru dengan ukuran 80 x 120 x $140 \mathrm{~nm}$ yang mempunyai tonjolan pada amplopnya (Murphy et al., 1972; Calisher et al., 1989). Bovine ephemeral fever memiliki berbagai nama lokal seperti demam 3 hari (3-day sickness), bovine enzootic fever, bovine influenza atau stiffseitke (Akakpo, 2015; Walker and Klement, 2015). Virus BEF masih satu kelompok dengan virus rabies, vesicular stomatitis dan strain yang ada memiliki kesamaan secara antigenik, meskipun berbeda dalam hal virulensi (Walker 
et al., 1991). Berdasarkan hasil hasil penelitian, saat ini di seluruh dunia dikenal 4 serotipe dan hanya satu serotipe virus BEF yang bersifat patogen (Kemp et al., 1973; Kaneko et al., 1986; Kato et al., 2009). Berbagai uji netralisasi yang dilakukan menggunakan isolat dari Australia, Cina, Jepang, Kenya, Nigeria dan Afrika Selatan telah menunjukkan reaksi silang antigenik yang kuat (Snowdon, 1970; Kemp et al., 1973; Tian et al., 1987).

Penularan BEF telah diketahui sejak lama tidak dapat terjadi dari sapi ke sapi secara kontak langsung (Mackerras et al., 1940). Pendapat tersebut didukung oleh St George (1988) dan Nandi and Negi (1999) yang menyatakan bahwa BEF tidak ditularkan melalui kontak secara langsung, urin, feses, daging, susu atau aerosol. Hasil penelitian dan observasi menunjukkan adanya bukti bahwa peningkatan risiko penyebaran BEF virus antar benua dapat melalui transportasi hewan atau translokasi vektor (Aziz-Boaron et al., 2012; Trinidad et al., 2014). PenyakitBEF ditransmisikan melalui vektor serangga, yang banyak terdapat di daerah tropis dan subtropis seperti Asia, Afrika dan Australia (Cybinski and Zakrzewski, 1983; Hamblin et al., 1990; Maiti et al., 2013). Nyamuk dari golongan Culicoides sp., Aedes sp. dan Culex $s p$. dapat bertindak sebagai vektor penyakit BEF (Muller and Standfast, 1986; Stram et al., 2005) dan telah dibuktikan dengan hasil isolasi virus BEF dari berbagai spesies nyamuk tersebut (Venter et al., 2003). Virus BEF pertama kali diisolasi dari campuran spesies Culicoides di Kenya (Davies and Walker, 1974), sedangkan di Zimbabwe virus dapat diisolasi dari C. Coarctatus dan C. imicola (Blackburn et al., 1985). Standfast et al., (1984) menyatakan bahwa virus BEF juga telah berhasil diisolasi dari nyamuk Anopheles bancroftii, meskipun distribusinya terbatas pada daerah tropis sehingga bukan merupakan vektor utama di Australia. Hasil penelitian Muller dan Standfast (1993) di Australia menunjukkan bahwa spesies nyamuk yang tersebar luas seperti Culex annulirostris adalah vektor virus BEF potensial. Hal tersebut dibuktikan dengan ditemukannya virus BEF di air liur Culex annulirostris 6-8 hari setelah diinfeksi. Virus BEF hanya menyebar setelah multipliksi pada tubuh vektor nyamuk dan masa inkubasi bervariasi antara 2-5 hari dengan maksimum 10-11 hari. Viremia dalam banyak kasus biasanya berlangsung singkat yaitu 3 atau 5 hari (St George, 1994).

Sejumlah bukti yang signifikan menunjukkan bahwa penyebaran virus BEF dalam wilayah geografis terjadi karena perpindahan vektor yang disebarkan melalui angin. Penyebaran BEF di Australia selama 1968-1969 dipengaruhi oleh kombinasi monsoonal dan tekanan udara rendah yang kuat di pedalaman Queensland (Newton and Wheatley, 1970). Pernyataan tersebut didukung oleh St George (1998) yang menyatakan adanya kemungkinan bahwa serangga terinfeksi dapat terbawa oleh angin dan menjadi penyebab penyebaran BEF di berbagai negara. Seller (1980) menambahkan bahwa Israel dan daerah Mediterania lain yang berada di zona "C", di mana vektor terinfeksi yang terbawa oleh angin akan menyebabkan munculnya wabah BEF. Wabah BEF terjadi ketika vektor yang kemungkinan besar adalah nyamuk mengalami peningkatan populasi sehingga menghasilkan tingkat transmisi virus yang tinggi untuk ternak yang rentan. Kejadian penyebaran BEF di Jepang kemungkinan salah satunya juga disebabkan oleh angin. Analisis menggunakan model penyebaran atmosfer menunjukkan bahwa lintasan penyebaran BEF dari pulau Ishigaki menuju ke pulau disekitarnya terjadi sekitar 1 minggu sebelum penyakit tersebut terdeteksi di setiap pulau. Hasil tersebut menunjukkan bahwa penyebaran vektor yang terinfeksi oleh angin dapat terjadi dari Pulau Ishigaki ke pulau disekitarnya (Hayama, et al., 2016).

\section{Epidemiologi BEF}

Penyakit BEF merupakan penyakit vectorborne disease, ditransmisikan melalui vektor serangga yang banyak terdapat di daerah tropis dan subtropis seperti Asia, Afrika dan Australia. Kejadian BEF dipengaruhi oleh beberapa faktor seperti adanya bendungan air (Yeruham et al., 2010), sistem irigasi yang kurang baik (Bett et al., 2017), perubahan lingkungan, cuaca dan iklim (Kasem et al., 2014; Mirzaie et al., 2017), perpindahan ternak (Murray, 1997), vektor (Mellor, 1996: Thomson and Connor 2000) dan mekanisasi pertanian (Sutherst, 2004). Kejadian BEF bersifat musiman di daerah beriklim sedang 
sehingga sebagian besar kasus dilaporkan pada akhir musim panas dan musim gugur (Yeruham et al., 2010). Kejadian BEF biasanya akan berakhir setelah memasuki awal musim dingin, sehingga kasus BEF tidak mungkin didiagnosis di pertengahan musim dingin atau awal musim semi ketika jumlah vektor sangat sedikit (Braverman, 2001). Namun, di daerah tropis dan subtropis, penyakit BEF dapat terjadi kapan saja sepanjang tahun (Coetzer, 1993).

Kejadian BEF saat ini dianggap lazim di bagian tropis benua Asia, Afrika, dan Australia (Newton and Wheatley, 1970; Gard et al., 1983; Walker, 2005; Finlaison et al., 2010). Infeksi BEF dianggap sebagai penyakit endemik di Afrika (Davies et al., 1999; Bastawecy et al., 2009; Vorster and Mapham, 2013) dan sebagian besar wilayah Timur Tengah seperti Israel, Yordania, Saudi Arabia, Suriah, Irak, Turki, dan Iran (Boorman, 1989; Yeruham et al., 2010; Aziz-Boaron et al., 2012; Finlaison et al., 2014; Bakhshesh and Abdollahi, 2015). Kejadian BEF juga telah banyak dilaporkan di beberapa bagian negara Asia, seperti Cina (Bai et al., 1991; Zheng et al., 2011), Taiwan (Liao et al., 1998), Jepang (Hirashima et al., 2017), Korea Selatan (Shin et al., 2009), India (Malviya and Prasad, 1977), Pakistan (Asi et al., 1999), Filipina (Dumag, 1977), Thailand (Wongwatcharadumrong et al., 1984), dan Indonesia (Miura et al., 1991; Suwito and Nurini, 2009; Nururrozi et al., 2017).

Sekitar tahun tahun 2012, kasus BEF telah didokumentasikan di Turki, meskipun pada tahun sebelumnya kasus BEF telah dilaporkan di wilayah Tenggara Turki yang merupakan berbatasan dengan Suriah, Irak dan Iran (Aziz-Boaron et al., 2012). Meskipun demikian, dugaan kejadian BEF dengan kematian tinggi telah didokumentasikan di banyak wilayah Turki pada tahun 2012. Melihat lokasi geografis Turki, ada kemungkinan bahwa penyakit tersebut dapat menyebar ke negaranegara Eropa seperti Yunani dan Bulgaria (Tonbak et al., 2013). Menurut Oğuzoğlu et al. (2015) wabah muncul secara berkala setiap 4-5 tahun di wilayah yang sama di Turki. Hal tersebut kemungkinan karena wilayahnya terletak di zona iklim subtropis yang merupakan kondisi optimal untuk perkembangan populasi vektor ada.
Di Jepang, epidemi BEF telah terjadi berulang kali sejak tahun 1950 (Shirakawa et al., 1994). Selama wabah pada tahun 1949-1951, dari total 770.000 kasus, lebih dari 10.000 kematian telah dilaporkan (Hirashima et al., 2017). Wabah BEF di Jepang selanjutnya muncul pada tahun 1989 dan 2001 yang berdampak pada 1000 lebih sapi di Okinawa, kepulauan di wilayah paling barat daya Jepang yang bersifat subtropis. Sedangkan tahun 2002 dan 2004, muncul wabah lagi dengan skala kecil dan pada tahun 2012 muncul lagi wabah BEF di kepulauan tersebut (Niwa et al., 2015). Wabah yang cukup menarik perhatian adalah yang terjadi di Prefektur Fukuoka, Jepang pada tahun 1988 dan 1991, terjadi sekitar 1 bulan setelah wabah BEF di Korea. Analisis meteorologi menunjukkan bahwa aliran angin melalui Provinsi Jeonnam di Korea melanda Prefektur Fukuoka Jepang selama wabah. Munculnya wabah BEF Prefektur Fukuoka mungkin berasal dari vektor yang terinfeksi yang dibawa oleh aliran angin (Shirakawa et al., 1994).

Kejadian BEF di Cina pertama kali dilaporkan di Provinsi Jiangsu (utara Shanghai) pada tahun 1934 ketika penyakit itu disebut bovine influenza. Sejak 1955, BEF telah tercatat di semua provinsi kecuali Xinjiang dan Qinghai di barat, Heilongjiang timur laut, Tianjin dan Hebei (Bai et al., 1993). Survei serologi telah dilakukan di 26 provinsi di Cina antara Januari 2012 sampai Juni 2014 dan hasil survei menunjukkan bahwa dari 2822 sampel serum yang dikumpulkan dari berbagai spesies ternak di 26 provinsi di Cina, $0 \%$ - 81\% menunjukkan hasil seropositif untuk virus BEF (Li et al., 2015).

Di Indonesia, penyakit Bovine Ephemeral Fever (BEF) dilaporkan telah ada sejak jaman penjajahan Belanda, dan ada dugaan kuat bahwa Australia mendapatkan penyakit BEF dari Indonesia (Astiti, 2010). Berdasarkan gejala klinis, BEF yang menyebabkan kematian pada sapi dewasa pertama kali dilaporkan tahun 1978. Setelah itu kasus BEF banyak dilaporkan dengan tingkat kematian saat itu mencapai 73\% di Jawa Timur. Namun demikian, tingginya angka kematian tersebut diduga merupakan komplikasi dengan infeksi bakteri Hemorrhagic Septicaemia (HS) (Ronohardjo dan Rastiko 1982). Winoto dan Sjafarjanto (2014) menyatakan bahwa tingkat Prevalensi kejadian BEF selama bulan April 
2012 hingga Juni 2013 di 23 desa di kecamatan Soko Kabupaten Tuban, sangat kecil sekali, yaitu hanya terjadi 81 kasus atau $0,54 \%$ dari populasi sapi 15.000 ekor. Lebih lanjut, menurut Winoto dan Sjafarjanto (2014) iklim di Indonesia menguntungkan untuk keberlangsungan hidup vektor sepanjang tahun, sehingga penyakit BEF diperkirakan bersifat enzootik. Nururrozi et al. (2017) mencatat kejadian BEF di Gunungkidul, DIY selama periode Oktober hingga Desember 2016. Hasil anamnesa dan pemeriksaan gejala klinis di empat Unit Pengembangan Teknis (UPT) Puskeswan Nglipar, Karangmojo, Patuk dan Panggang pada periode tersebut diketahui tingkat kejadian BEF sangat tinggi mencapai 48\% yakni 134 kasus dari 277 kasus berbagai macam penyakit pada sapi yang ditangani. Lebih lanjut, hasil pengamatan tersebut juga menunjukkan adanya kecenderungan bahwa pada bulan basah atau musim penghujan yang dimulai pada bulan Oktober-November biasanya akan terjadi peningkatan jumlah vektor pembawa penyakit BEF yakni artropoda seperti nyamuk yang dapat terbang bersama angin dan banyak diamati di kandang.

Tindakan pengendalian yang efektif yang melibatkan berbagai pihak yang berkepentingan diperlukan untuk mencegah infeksi BEF. Hasil penelitian penelitian diatas dapat mendorong negara negara lain yang terkait untuk bekerja sama dalam pencegahan dari BEF. Studi epidemiologi di berbagai negara menunjukkan bahwa vektor biologis memiliki peran penting dalam kejadian BEF. Oleh sebab itu, pantauan secara menyeluruh terhadap kondisi lingkungan termasuk iklim dan cuaca yang mempengaruhi pergerakan vektor sangatlah diperlukan pada saat wabah BEF terjadi. Pantauan tersebut perlu dilakukan guna menerapkan langkah-langkah pengendalian yang efektif. Selain hal tersebut, deteksi dini dan pengobatan selanjutnya dari kasus yang teridentifikasi adalah kunci keberhasilan untuk mengendalikan penyakit BEF.

\section{Gejala dan Diagnosa BEF}

Bovine Ephemeral Fever kemungkinan memiliki distribusi yang lebih luas daripada yang mungkin terdokumentasi karena gejala klinis yang relatif ringan dan tingkat pemulihan kesehatan yang baik dalam banyak kasus. Untuk alasan yang sama kemungkinan dapat menyebabkan ketidak tepatan diagnosis atau diagnosis tidak dikonfirmasi lebih lanjut dengan metode pendukung oleh praktisi. Diagnosis BEF dapat dilakukan dengan melihat gejala klinis dan uji laboratoris seperti hematologis, pemeriksaan patologis, serologis, dan virologis (Bayer, 1998). Namun demikian, konfirmasi diagnosa laboratorium tersebut membutuhkan waktu, tenaga dan biaya yang mahal, selain itu, metode deteksi virus tidak selalu dapat diandalkan dan tidak jarang menghasilkan negatif palsu (Nandi and Negi, 1999).Gejala klinis penyakit BEF yang sering teramati adalah demam tinggi selama 2-5 hari dan kemungkinan dapat sembuh spontan tanpa pengobatan (Burgess and Sprawbrow, 1977;Hsieh et al., 2005). Gejala klinis lain yang sering muncul adalah adanya leleran hidung, radang sendi dan kekakuan otot (Walker, 2005). Namun demikian konfirmasi lanjut untuk peneguhan diagnosa masih perlu dilakukan dengan uji serologis ataupun virologis dengan isolasi dan identifikasi virus karena gejala klinis yang muncul tidak bersifat patognomonik. Tabel 1 . menunjukkan variasi gambaran gejala klinis yang ditemukan pada kejadian BEF. Semua penderita BEF menunjukkan gejala yang menciri yaitu demam, pincang dan kekakuan alat gerak (Budhi, 2011). Meskipun demikian, untuk memastikan diagnosis BEF harus dilakukan pemeriksaan lain seperti hematologis, serologis dan virologis sehingga dapat menghindari diagnosa banding dengan gejala yang mirip seperti contohnya adalah post-parturient hypocalcaemia (milk fever).

Hewan terinfeksi BEF akan menunjukkan gambaran hematologi dan perubahan biokimia tertentu yang dapat mendukung penentuan diagnosis. Hasil pemeriksaan darah pada sapi potong penderita $\mathrm{BEF}$ menunjukkan adanya netrofilia (Abu Elzein et al., 1977). Menurut Uren dan Murphy (1985) dan Young dan Spradbrow (1990), reaksi demam biasanya bertepatan dengan neutrofilia. Hasil pemeriksaan darah yang sering diamati pada kasus BEF adalah leukopenia, netrofilia, penurunan kalsium serum dan peningkatan fibrinogen plasma, hasil pemeriksaan tersebut dapat dijadikan sebagai bahan pertimbangan saat menentukan strategi pengobatan (Uren et al., 1985). Hasil pemeriksaan darah oleh Burgess and Spradbrow (1977) pada sapi penderita BEF menunjukkan gambaran 
Tabel 1. Gejala klinis BEF

\begin{tabular}{|c|c|c|}
\hline Gejala klinis & Hewan & Pustaka \\
\hline $\begin{array}{l}\text { Demam, pembengkakan limfoglandula superfisial, hipersalivasi, kekakuan otot, } \\
\text { leleran hidung, penurunan produksi susu }\end{array}$ & Sapi perah & Theodoridis et al., 1973 \\
\hline Demam, anoreksia gangguan pernapasan, pincang, malas bergerak & Sapi potong & Abu Elzein et al., 1977 \\
\hline $\begin{array}{l}\text { anoreksi, pincang dan/atau gaya berjalan kaku; pembengkakan limfoglandula } \\
\text { superfisial, demam, atoni rumen, depresi produksi susu menurun tajam }\end{array}$ & Sapi perah & Prasad et al., 1997 \\
\hline $\begin{array}{l}\text { Demam tinggi, anoreksi, pincang, produksi susu menurun tajam, konstipasi/diare, } \\
\text { kekakuan otot }\end{array}$ & Sapi perah & Sah, 2002 \\
\hline $\begin{array}{l}\text { penurunan produksi susu, demam, } \\
\text { kekakuan dan kepincangan alat gerak, ambruk }\end{array}$ & Sapi perah & Thabet et al., 2011 \\
\hline $\begin{array}{l}\text { Demam, anoreksia, dyspnea, ambruk, kekakuan otot, pincang, leleran hidung, } \\
\text { penurunan produksi susu }\end{array}$ & Sapi perah & Zaghawa et al., 2017 \\
\hline Demam, anoreksia, ambruk, leleran hidung & Sapi potong & Barigye et al., 2017 \\
\hline Anoreksi, demam, pincang, ambruk, leleran hidung, hipersalivasi & Sapi potong & Nururrozi et al., 2017 \\
\hline
\end{tabular}

neutrofilia dan limfopenia. Gambaran limfopenia menunjukkan kemungkinan adanya stress pada hewan penderita BEF. Thabet et al. (2011) mencoba untuk menganalisis gambaran biokimia darah pada sapi penderita BEF. Hasil penelitiannya menunjukkan gambaran limfopenia, hipokalsemia, hiponatremia, hiperkloremia, hipokalemia, hipoglobulinemia dan peningkatan kortisol. Menurut Uren et al. (1992) dan Charbonneau et al. (2006) salah satu masalah yang perlu mendapatkan perhatian pada ternak yang terinfeksi BEF adalah kondisi hipokalsemia yang memunculkan gejala gejala klinis serupa dengan kasus milk fever, meskipun pada kasus BEF kondisi yang menyebabkan hipokalsemia belum jelas penyebabnya. Thabet et al. (2011) menambahkan bahwa gejala klinis BEF diduga tampaknya terkait dengan kondisi hipokalsemia. Dugaan tersebut dilandasi adanya tekanan pada hormon paratiroid yang tampaknya dimediasi oleh kondisi alkalosis respiratorik akibat BEF. Penjelasaan tersebut masih perlu dikaji melalui penelitian penelitian yang dapat mengkaitkan hubungan antara status asam basa, analisa status biokimia darah dan urin penderita BEF.

Pada kasus BEF, sebagian besar diagnosa yang disimpulkan dari hasil pemeriksaan klinis dapat dilanjutkan dengan konfirmasi uji serologi (Sendow, 2013). Peningkatan titer antibodi dapat digunakan untuk membantu meneguhkan diagnosa BEF. Selain titer antibodi, uji fiksasi komplemen (CFT) juga digunakan untuk diagnosa $\mathrm{BEF}$ meskipun hanya mampu mengidentifikasi antibodi spesifik Ephemerovirus (Bai et al., 1987). Saat ini, virus neutralisation test (VNT) atau
ELISA merupakan uji serologis yang paling sering digunakan karena mampu membedakan virus BEF dari anggota genus Ephemerovirus lain (Nandi and Negi, 1999; Bastawecy, 2011). Saat ini, isolasi virus tampaknya menjadi metode standar untuk diagnosa BEF dan selanjutnya virus yang terisolasi dapat diidentifikasi dengan metode indirect Fluorescent antibody technique (IFAT), VNT dan mikroskop elektron (St George, 1998; Tuppuraunen, 2004). Diagnosa BEF dengan ELISA pernah dilakukan oleh Balai Besar Penelitian Veteriner untuk membedakana dengan penyakit lain terutama Peste des petits ruminants (PPR), Rinderpest, Bluetongue, dan Pasteurellosis (Sendow et al., 2017). Uji diagnostik molekuler yang dapat digunakan untuk diagnosa $\mathrm{BEF}$ antara lain adalah imunohistokimia, PCR, RT-PCR, real- time RTqPCR (Bakhshesh and Abdollahi, 2015; Zaghawa et al., 2017; Barigye et al., 2017). Sedangkan uji diagnostik molekuler yang telah dikembangkan untuk mendeteksi BEF adalah metode Real-time PCR/RT-PCR dan reverse transcription loopmediated isothermal amplification/RTLAMP dan kedua metode tersebut sangat sensitif terhadap gen $\mathrm{G}$ yang menjadi targetnya (Stram et al., 2005; Zheng et al., 2011). Dibandingkan dengan RTPCR, uji RTLAMP memiliki kelebihan karena tidak membutuhkan peralatan khusus untuk proses thermal cycling (Johnson et al., 2012).

\section{Terapi dan Pencegahan BEF}

Pengobatan mungkin tidak diperlukan dalam kasus BEF ringan, tetapi pada kondisi yang lebih parah perlu diberikan obat anti radang (Uren et 
al., 1989). Pada kondisi lebih berat dimana hewan ambruk dengan menunjukkan gejala hipokalsemia sekunder maka perlu diberikan terapi tambahan dengan kalsium boroglukonat (St George, 1988). Pengobatan tidak efektif pada kondisi yang parah, namun pemberian antibiotik, anti radang dan cairan pengganti dinilai cukup efektif untuk mengurangi terjadinya infeksi sekunder dan mengatasi dehidrasi yang kemungkinan dapat memperparah kondisi hewan serta berakibat fatal. Sah (2002) menggunakan kombinasi natrium diklofenak $1 \mathrm{mg} / \mathrm{kg}$ berat badan setiap hari selama 3 hari berturut-turut dengan oksitetrasiklin LA $20 \mathrm{mg} / \mathrm{kg}$ berat badan memberikan hasil yang signifikan untuk terapi BEF. Terapi kejadian BEF pada sapi potong lokal jenis peranakan ongole (PO) oleh para praktisi dokter hewan di Gunungkidul, DIY sebagian besar menggunakan kombinasi antara antipiretik, antibiotik, antihistamin dan vitamin. Kombinasi tersebut memberikan tingkat kesembuhan yang baik berdasarkan informasi dari petugas yang mendapat laporan dari peternak pasca penanganan dengan tidak adanya kejadian berulang (Nururrozi et al., 2017). Terapi anti radang menurut Uren et al. (1989) efektif dalam mencegah timbulnya gejala klinis saat diberikan setiap hari selama periode inkubasi dan berdampak pada kesembuhan yang cepat ketika diberikan setelah munculnya gejala klinis.

Program pencegahan dan pengendalian dapat juga dilakukan melalui vaksinasi pada ternak. Program vaksinasi dilakukan untuk meningkatkan kekebalan terhadap penyakit BEF (Wallace and Viljoen 2005). Pada awalnya, vaksin yang tersedia berasal dari virus yang dilemahkan (live attenuated virus) dan killed virus meskipun kemungkinan kurang dapat diandalkan (Uren, 1989; ElBagoury et al., 2016). Namun seiring dengan perkembangan penelitian, saat ini telah tersedia 4 bentuk vaksin, yaitu live-attenuated vaccines, inactivated vaccines, sub-unit $G$ protein-based vaccines recombinant vaccines dengan efikasi dan kemampuan perlindungan yang bervariasi (Liu and Munir, 2013). Walker and Klement (2015) menambahkan bahwa untuk meningkatkan efikasi dan kemampuan perlindungan dari vaksin $\mathrm{BEF}$ diperlukan vaksinasi booster dengan interval 6 bulan hingga 1 tahun. Meskipun demikian, di daerah endemik, vaksinasi BEF tidak banyak berpengaruh terhadap pencegahan penyakit BEF (Sendow, 2013). Sampai saat ini, vaksinasi BEF telah dilakukan ke berbagai negara seperti Australia, kawasan Asia meliputi Jepang, Korea Selatan, Taiwan, Cina, Filipina, Israel, Kuwait, Oman, Bahrain, Arab Saudi (Song and Kang, 1970; Inaba et al., 1973; Walthall and Vanselow, 1986; Chiu et al., 1987; Bai et al., 1993; Aziz-Boaron et al., 2015; Walker and Clement, 2015). Sedangkan di Afrika vaksinasi BEF telah dilakukan di Afrika Selatan, Namibia, dan Mesir (Theodoridis et al., 1973; Erasmus, 1986; El-Bagoury et al., 2016). Vaksinasi BEF dapat diberikan pada ternak yang belum mempunyai kekebalan terhadap BEF namun rawan terhadap infeksi BEF. Pada umumnya vaksinasi dapat diberikan pada sapi umur di atas tiga bulan hingga dewasa.

Upaya pencegahan penyakit BEF juga didasarkan pada pengendalian vektor arthropoda dan menerapkan kebersihan ternak serta lingkungannya untuk mengurangi risiko penyebaran. Meskipun demikian, upaya pencegahan tersebut hasilnya terbatas, terutama di negara-negara di mana pemeliharaan ternak masih menggunakan sistem penggembalaan dan kurangnya perhatian terhadap kebersihan sehingga pengendalian vektor tidak sepenuhnya memuaskan (Akakpo, 2015). Cara lain upaya pencegahan BEF adalah melalui kontrol risiko yang terkait dengan pergerakan sapi terinfeksi. Pergerakan sapi terinfeksi melalui transportasi cepat dengan jarak tempuh yang relatif pendek serta waktu karantina yang singkat dalam daerah bebas vektor harus dikontrol secara cermat untuk menghindari penularan BEF dari lain daerah terkait dengan singkatnya kejadian viremia (3-5 hari) segera setelah terinfeksi virus BEF (Kirkland, 2002; St George 2004; Trinidad et al., 2014). Pada akhirnya, pengendalian dan kontrol penyakit BEF sangat tergantung pada pembatasan ruang gerak ternak, karantina ternak terduga maupun penderita, pelaksanaan karantina ternak baru pada area bebas vektor, kontrol vektor, vaksinasi dan pengobatan hewan sakit.

\section{Kesimpulan}

Bovine ephemeral fever (BEF) adalah penyakit viral yang ditularkan oleh serangga 
(arthropod borne virus), famili Rhabdoviridae dan genus Ephemerovirus. Teknik diagnosis yang cepat dan akurat perlu dikembangkan baik uji serologi maupun deteksi virus sehingga wabah penyakit BEF dapat diantisipasi lebih dini. Meskipun pengobatan dinilai tidak efektif, namun pemberian antibiotik, antiinflamasi, pemberian cairan dinilai cukup efektif untuk mengurangi terjadinya infeksi sekunder, yang dapat memperparah kondisi hewan, dan dapat berakibat fatal. Pencegahan penyakit dapat dilakukan dengan memperhatikan hygiene dan sanitasi kandang dan ternak yang optimal.

\section{Daftar Pustaka}

Abu-Elzein, E. M. E., Gameel, A. A., Al Afaleq, A. I., Al Gundi, O. and Bukhari, A. (1977) Bovine ephemeral fever in Saudi Arabia Veterinary Record. 140: 630-631. http:// dx.doi.org/10.1136/vr.140.24.630

Akakpo, A.J. (2015) Three-day fever. Rev. Sci. Tech. Off. Int. Epiz. 34 (2): 533-538

Anderson, E.C. and Rowe, L.W. (1998) The prevalence of antibody to the viruses of bovine virus diarrhoea, bovine herpes virus 1, Rift Valley fever, ephemeral fever and bluetongue and to Leptospira sp in free-ranging wildlife in Zimbabwe. Epidemiol Infect $121 \quad$ (2):441-449. PMCID: PMC2809544 PMID: 9825798

Asi, M. N., Muhammad, G., Saqib, M. and Inayat, A. (1999) A preliminary clinical report on the occurrence of bovine ephemeral fever among crossbred cattle in Pakistan Pakistan Vet. J. 19 (2): 98-100

Astiti, L.G.S. (2010) Petunjuk Praktis Manajemen Pencegahan dan Pengendalian Penyakit PadaTernak Sapi. Balai Pengkajian Teknologi Pertanian Ntb. Balai Besar Pengkajian Dan Pengembangan Teknologi Pertanian. Badan Penelitian Dan Pengembangan Pertanian. Kementerian Pertanian. ntb.litbang.pertanian.go.id/ind/ $\mathrm{pu} / \mathrm{psds} /$ Penyakit.pdf?secure $=$ true

Aziz-Boaron, O., Brettschneider, S., King, R., Gelman, B. and Klement, E. (2015) Seroprevalencelof Bovine Ephemeral Fever
Virus in Domesticated and Wildlife Species during Epidemic and Inter-epidemic Periods (2000-2009) in Israel. Transboundary and Emerging Diseases. 62(2): 183-187. https:// doi.org/10.1111/tbed.12104

Aziz-Boaron, O., Klausner, Z., Shenkar, J., Gafni, O., Gelman, B., David, D. and Klement, E. (2012) Circulation of bovine ephemeral fever in the Middle-East-strong evidence for transmission by winds and animal transport. Vet Microbiol 158 (3-4): 300307. DOI:10.1016/j.vetmic.2012.03.003

Bai, W., Yan, J., Zhang, Z., Jiang, C. and Lin, $X$. (1993) Studies on a vaccine against ephemeral fever. In: St George TD, Uren MF, Young PL, Hoffmann D (eds) Proceedings of the 1st International Symposium on Bovine Ephemeral Fever and Related Rhabdoviruses, Beijing, August 1992. Australian Centre for International Agricultural Research Proceedings 44, 111114.

Bai, W.B., Jiang, C.L. and Davis, S.S. (1991) Preliminary observations on the epidemiology of bovine ephemeral fever in China. Trop Anim Health Prod. 23(1):2226.PMID:2038767

Bai, W.B., Tian, F.L., Wang, C., Jiang, C.L. and Zhang, Z.G. (1987) Preliminary studies of the complement fixation test to confirm the diagnosis of bovine ephemeral fever. Aust J Biol Sci. 40(2):137-41. DOI: 10.1071/ BI9870137

Bakhshesh, M. and Abdollahi, D. (2015) Bovine Ephemeral Fever in Iran: Diagnosis, Isolation and Molecular Characterization. J Arthropod-Borne Dis. 9(2): 195-203 PMCID: PMC4662791

Barigye, R., Davis, S., Hunt, R., Hunt, N., Walsh, S., Elliott, N., Dyrting, K., Weira, R. and Melvillea, L.F. (2017) CASE REPORT: Post-viraemic detection of bovine ephemeral fever virus by use of autogenous lymphoid tissue-derived bovine primary cell cultures. Aust Vet J. 95(1-2):49-52 doi: 10.1111/ avj.12551 
Barnard, B.J. (1997) Antibodies against some viruses of domestic animals in southern African wild animals. Onderstepoort J Vet Res 64 (2): 95-110.PMID:9352558

Bastawecy, I. M., Mahmoud, N.A., Eweis, M. and Salem, S.A.H. (2009) Evaluation of different diagnostic techniques of bovine ephemeral fever virus in cattle. Egypt J.Comparative Pathology and Clinical Pathology. 23 (2): 7-17.

Bastawecy, I. M., Saad, M. A. M., Abd El-Samee, A. A. and Youssef, H. M. (2011) Electron Microscopic Characterization of Bovine Ephemeral Fever Virus. Journal of American Science, 7(12): 612-617

Bayer, 1998. Bovine ephemeral fever, in Exotic Animal Disease, the grey book. Bayer: 109115.

Bett, B., Said, M.Y., Sang, R., Bukachi, S., Wanyoike, S., Kifugo, S.C., Otieno, F., Ontiri, E., Njeru, I., Lindahl, J. and Grace, D. (2017) Effects of flood irrigation on the risk of selected zoonotic pathogens in an arid and semi-arid area in the eastern Kenya. PLoS ONE 12(5): e0172626. https://doi. org/10.1371/journal.pone.0172626

Blackburn, N.K., Searle, L. and Phleps, R.J. (1985) Viruses isolated from Culicoides (Diptera: Ceratopogonidae) caught at a veterinary research farm, Mazowe, Zimbabwe. J Entomol Soc South Afr 48 (2):331-336

Budhi, S., Sumiarto, B., Budiharta, S. (2007). Prevalensi dan Faktor Resiko Penyakit Footrot pada Sapi Perah di Kabupaten Sleman. Jurnal Sain Veteriner 25 (2): 57-60

Budhi, S. (2011). Analisis Penyebab dan Faktor Resiko Terjadinya Pincang pada Sapi Perah di Kecamatan Pakem, Kabupaten Sleman, Yogyakarta. Jurnal Sain Veteriner, Vol 29 (2): $71-76$

Boorman, J. (1989) Culicoides (Diptera: Ceratopogonidae) of the Arabia peninsula with notes on their medical and veterinary importance. Fauna Saudi Arabia, 10: 160224.

Braverman, Y. (2001) The vectors of bovine ephemeral fever, Akabane and bluetongue viruses in Israel," in Proceedings of the 13th Symposium of Dairy Cattle Science, 81-82, Zichron Yaakov, Israel, February 2001.

Burgess, G. W. and Spradbrow, P. B. (1977) Studies On The Pathogenesis Of Bovine. Ephemeral Fever. Australian Veterinary Journal. 53(8): 363-368. https://doi. org/10.1111/j.1751-0813.1977.tb07952.x

Calisher, C. H., Karabatsos, N., Zeller, H., Digoutte, J.P., Tesh, R. B., Shope, R. E., Travassos Da Rosa, A. P. A. and St George, T. D. (1989) Antigenic relationships among rhabdoviruses from vertebrates and haematophagous arthropods. Intervirotogy 30 (5): 241- 257. DOI:10.1159/000150100

Charbonneau, E., Pellerin, D. and Oetzel, G.R. (2006) Impact of Lowering Dietary Cation-Anion Difference in Nonlactating Dairy Cows: A MetaAnalysis. J Dairy Sci.89(2):537-548. DOI: https://doi. org/10.3168/jds.S0022-0302(06)72116-6

Chiu, S.Y. and Lu, Y.S. (1987) The prophylaxis of bovine ephemeral fever in Taiwan. J. Chinese Soc. Vet. Sci. 13:189-195.

Coetzer, J.A.W. (1993) The diagnosis and differential diagnosis of bovine ephemeral fever in southern Africa. In: St George TD, Uren MF, Young PL, Hoffmann D (eds) Proceedings of the 1st International Symposium on Bovine Ephemeral Fever and Related Rhabdoviruses, Beijing, August 1992. Australian Centre for International Agricultural Research Proceedings 44: 7073

Cybinski, D.H. and Zakrzewski, H. (1983) The isolation and preliminary characterization of a rhabdovirus in Australia related to bovine ephemeral fever virus. Vet. Microbiol. 8(3):221-235. DOI: $10.1016 / 0378$ 1135(83)90075-5

Davies, F.G., Ochieng, P. and Walker, A.R. (1990) The occurrence of ephemeral fever in Kenya, 1968-1988. Vet. Microbiol. 22(23):129-136. https://doi.org/10.1016/03781135(90)90100-A

Davies, F. G., Shaw, T. and Ochieng, P. (1975) Observations on the epidemiology of 
ephemeral fever in Kenya. J. Hyg. Camb. 75(2): 231-235.PMCID:PMC2130305

Davies, F.G. and Walker, A. (1974) The isolation of ephemeral fever virus from cattle and culicoides midges in Kenya. Vet. Rec. 95 (3):63-64. http://dx.doi.org/10.1136/ vr.95.3.63

Dumag, P.U. (1977) Livestock diseases and parasites, prevention and its control. Philipp. J. Anim. Ind. 32:127-143

El-Bagoury, G.F., El-Habbaa, A.S., Amal, A.M. and Nermeen, G.S. (2016) Efficacy of inactivated BEF vaccine adjuvant with Montanide ISA 206 compared with the locally prepared inactivated BEF vaccines. BVMJ. 31(2): 117-123.

Erasmus, B.J. (1986) The use of live ephemeral fever vaccine in South Africa. In: St George TD, Kay BH, Blok J (eds) Proceedings of the 4th Symposium on Arbovirus Research in Australia, Brisbane, May 1986. CSIROQIMR, pp 318-319

Finlaison, D.S., Read, A.J., Zhang, J., Paskin, R. and Kirkland, P.D. (2014) Application of a real-time polymerase chain reaction assay to the diagnosis of bovine ephemeral fever during an outbreak in New South Wales and northern Victoria in 2009-10. Aust. Vet. J. 92(1-2): 24-27. DOI:10.1111/avj.12139

Finlaison, D.S., Read, A.J. and Kirkland, P.D. (2010) An epizootic of bovine ephemeral fever in New South Wales in 2008 associated with long-distance dispersal of vectors. Aust. Vet. J. 88(8): 301-306. doi: 10.1111/j.1751-0813.2010.00596.x.

Gard, G.P., Cybinski, D.H. and St. George, T.D. (1983) The isolation in Australia of a new virus related to bovine ephemeral fever virus. Aust. Vet. J. 60 (3): 89-90. https://doi. org/10.1111/j.1751-0813.1983.tb05882.x

Hamblin, C. (2008) Bovine ephemeral fever. In: Foreign animal diseases. Boca Raton, FL: United States Animal Health Association. 175-183.

Hamblin, C., Anderson, E.C., Jago, M., Mlengeya, T. and Hipji, K. (1990) Antibodies to some pathogenic agents in free-living wild species in Tanzania. Epidemiol. Infect. 105(3):585-594.https://doi.org/10.1017/ S0950268800048226

Hayama, Y., Moriguchi, S., Yanase, T., Suzuki, M., Niwa,T., Ikemiyagi, K., Nitta, Y., Yamamoto, T., Kobayashi, S., Murai, K. and Tsutsui, T. (2016) Epidemiological analysis of bovine ephemeral fever in 2012-2013 in the subtropical islands of Japan. BMC Veterinary Research. 12(47): 1-13 DOI 10.1186/s12917-016-0673-0

Hirashima,Y., Nojiri, M., Ohtsuka,Y., Kato,T., Shirafuji,H., Kurazono,M., Imafuji, T. and Yanase, T. (2017) Resurgence of bovine ephemeral fever in mainland Japan in 2015 after a 23-year absence. J. Vet. Med. Sci. 79(5): 904-911. doi: 10.1292/jvms.160345

Hsieh, Y.C., Chen, S.H., Chou, C.C., Ting, L.J., Itakura, C. and Wang, F.I. (2005) Bovine ephemeral fever in Taiwan (20012002). J. Vet. Med. Sci. 67 (4): 411-416. DOI: 10.1292/jvms.67.411

Inaba, Y., Kurogi, H., Sato, K., Goto, Y., Omori, T. and Matumoto, M. (1973) Formalininactivated, aluminum phosphate geladsorbed vaccine of bovine ephemeral fever virus. Arch. Gesamte. Virusforsch. 42(1): 42-53. doi: 10.1007/BF01250506

Johnson, N., Voller, K., Phipps, L.P., Mansfield, K. and Fooks, A.R. (2012) Rapid Molecular DetectionMethods for Arboviruses of Livestock of Importance to Northern Europe Journal of Biomedicine and Biotechnology. 2012 ( Article ID 719402): 1-18 doi:10.1155/2012/719402

Kaneko, N., Inaba, Y., Akashi, H. and Satou, K. (1986) Isolation of a new bovine ephemeral fever group virus. Aust. Vet. J.,63 (1): 29. https://doi.org/10.1111/j.1751-0813.1986. tb02870.x

Kasem, S., Dawod, A.S., Khodier, M., Kotb, A., abouelyazeed, M., kareem, S.A. and Ibrahim, B. (2014) Isolation and Characterization of Bovine Ephemeral Fever Virus in Delta Provinces, Egypt 2012. Global Veterinaria 
13 (6): 972-976. DOI: 10.5829/idosi. gv.2014.13.06.9128

Kato, T., Aizawa, M., Takayoshi, K., Kokuba, T., Yanase, T., Shirafuji, H., Tsuda, T. and Yamakawa, M. (2009) Phylogenetic relationships of the $\mathrm{G}$ gene sequence of bovine ephemeral fever virus isolated in Japan, Taiwan and Australia. Vet. Microbiol. 137:217-223. http://dx.doi.org/10.1016/j. vetmic.2009.01.021.

Kay, B.H., Carley, J.G. and Filippich, C. (1975) The multiplication of Queensland and New Guinean arboviruses in Culex annulirostris Skuse and Aedes vigilax (Skuse) (Diptera: Culicidae). J. Med. Entomol. 12 (3) :279-283. https://doi.org/10.1093/ jmedent/12.3.279

Kemp, G.E., Mann, E.D., Tomori, O., Fabiyi, A. and O'Connor, E. (1973) Isolation of bovine ephemeral fever virus in Nigeria. Vet. Rec. 93(4):107-108. http://dx.doi.org/10.1136/ vr.93.4.107

Kirkland, P. (2016) Bovine ephemeral fever: three day sickness. The Center for Food Security and Public Health. Ames, Iowa. Hal 1-4

Kirkland, P.D. (2002) Akabane and bovine ephemeral fever virus infections. Vet Clin Food Anim. Pract. 18 (3):501-514. DOI: $\quad$ https://doi.org/10.1016/S07490720(02)00026-9

Li, Z., Zheng, F., Gao, S., Wang, S., Wang, J., Liu, Z., Du, J. and Yin, H. (2015) Large-scale serological survey of bovine ephemeral fever in China. Vet. Microbiol. 176 1-2):155-160. doi: 10.1016/j.vetmic.2014.12.008.

Liao, Y.K., Inaba, Y., Li, N.J., Chain, C.Y., Lee, S.L and Liou, P.P. (1998) Epidemiology of bovine ephemeral fever virus infection in Taiwan. Microbiol. Res. 153(3):289-295. DOI:10.1016/S0944-5013(98)80014-1

Liu, H.J. and Munir, M. (2013) Bovine ephemeral fever virus. In: Mononegaviruses of veterinary importance. Volume I: Pathobiology and molecular diagnosis (ed. by Munir, M.) Wallingford, UK: CABI, 199-208. http://www.cabi.org/cabebooks/ ebook/20133399514
Mackerras, I. M., Mackerras, M. J. and Burnet, F. M. (1940) Experimental studies of ephemeral fever in Australian cattle. Counc. of Sci. dan Ind. Res. Australia. Bull. No. 136: 1- 116.

Maiti, S., Chakravarty, P., Garai, S., Bandyopadhyay, S. and Chouhan, V.S. (2013) Ethno-veterinary practices for ephemeral fever in yak: a partipatory assessment by the Monpa tribe of Arunachal Pradesh. Indian J. Trad. Knowl. 12:36-39

Malviya, H.K. and Prasad, J. (1977) Ephemeral fever - a clinical and epidemiological study in cross bred cows and buffaloes. Indian Vet J 54(6):440-444

Mellor, P. S. (1996) Culicoides: vectors, climate change and disease risk. Veterinary Bulletin. 66:301-306.

Mellor, P.S., Boorman, J. and Baylis, M. (2000) Culicoides biting midges: their role as arbovirus vectors. Annu. Rev. Entomol. 45:307-40.

DOI:10.1146/annurev. ento.45.1.307

Mirzaie, K., Bahonar, A., Mehrabadi, M.F., Hajilu, G. and Yaghoubi, M. (2017) Determinants of bovine ephemeral fever outbreak during 2013, in Qazvin Province, Iran. Asian Pac. J. Trop. Dis. 7(12): 744-747 https://doi. org/10.12980/apjtd.7.2017D7-22

Miura, Y., Inaba, Y., Tsuda, T., Tokuhisa, S., Sato, K., Akashi, H. and Matumoto, M. (1982) A survey of antibodies to arthropod-borne viruses in Indonesian cattle. Jpn. J. Vet. Sci. 44(6): 857-863. https://doi.org/10.1292/ jvms1939.44.857

Momtaz, H., Nejat, S., Moazeni, M. and Riahi, M. (2012) Molecular epidemiology of Bovine ephemeral fever virus in cattle and buffaloes in Iran. Revue Méd. Vét. 163 (8-9): 415-418

Muller, M. J. and Standfast, H. (1993) Investigation of the vectors of bovine ephemeral fever virus in Australia. In: Proceedings of the 1st International Symposium on Bovine Ephemeral Fever and Related Rhabdoviruses, Beijing, PRC, 25-27 August 1992 (St. George, T. D., Uren, M. F., Young, P. L. and Hoffmann, 
D. eds.). Australian Centre for International Agricultural Research Proceedings 44: 29 32.

Muller, M.J. and Standfast, H.A. (1986) Vectors of ephemeral fever group viruses. Arbovirus research in Australia. Proceedings Fourth Symposium May 6-9, 1986, Brisbane, Australia, 295-298

Murphy, F.A., Taylor, W.P., Mims, C.A. and Whitfield, S.G. (1972) Bovine ephemeral fever virus in cell culture and mice. Archives of Virology. 38(2):234-249. DOI: 10.1007/ BF01249675

Murray, M. D. (1997) Possible vectors of bovine ephemeral fever in the 1967/68 epizootic in northern Victoria. Aust. Vet. J. 75 (3): 220. https://doi.org/10.1111/j.1751-0813.1997. tb10073.X

Nandi, S. and Negi, B. S. (1999) Bovine ephemeral fever: a review. Comp Immunol Microbiol. Infect. Dis. 22 (2): 81-91. https://doi. org/10.1016/S0147-9571(98)00027-7

Newton, L.G. and Wheatley, C.H. (1970) The occurrence and spread of ephemeral fever of cattle in Queensland. Aust Vet J 46 (12):561-568. https://doi. org/10.1111/j.1751-0813.1970.tb06657.x

Niwa, T., Shirafuji, H., Ikemiyagi, K., Nitta, Y., Suzuki, M., Kato, T. and Yanase, T. (2015) Occurrence of bovine ephemeral fever in Okinawa Prefecture, Japan, in 2012 and development of a reverse-transcription polymerase chain reaction assay to detect bovine ephemeral fever virus gene. J. Vet. Med. Sci. 77(4):455-460. doi: 10.1292/ jvms.14-0492.

Nururrozi, A., Fitranda, M., Indarjulianto, S. and Yanuartono. (2017) Bovine Ephemeral Fever on cattle in Gunungkidul district, Yogyakarta (Case Report). Jurnal IlmuIlmu Peternakan 27 (1): 101-106. DOI : 10.21776/ub.jiip.2017.027.01.09

Ogawa, T. (1992) Epidemiological investigation of bovine ephemeral fever outbreaks in Kyusyu Island in Japan during the fall of 1988. Prev. Vet. Med. 14 (1-2):69-76. https://doi. org/10.1016/0167-5877(92)90085-T
Oğuzoğlu, T. Ç., Ertürk, A., Çizmeci, Ş. G., Koç, B. T. and Akça, Y. (2015) A Report on Bovine Ephemeral Fever Virus in Turkey: Antigenic Variations of Different Strains of EFV in the 1985 and 2012 Outbreaks Using Partial Glycoprotein Gene Sequences. Transboundary and Emerging Diseases. 62(5): e66-e70. https://doi.org/10.1111/ tbed. 12187

Prasad, B., Manuja, S., Kishtwaria, R. S., Rao, V. N. and Singh, R. J. (1997) Clinical report on ephemeral fever in cattle. Indian Veterinary Journal. 74 (8): 685-686

Ronohardjo, P. and Rastiko, P. (1982) Some epidemiological aspects and economic loss of Bovine Ephemeral Fever outbreak in Tuban and surrounding areas East Java, Indonesia. Penyakit Hewan 14:25-29.

Roya, S. (2008) Survey on serological diagnosis of Bovine Ephemoral Fever (BEF) by IR-BK and Vero cell lines in Southern provinces of Iran by in vitro methods, 15 th congress of FAVA, 2008, Bangkok, Thailand.

Sah, J. (2002) A Clinical Study on Bovine Ephemeral Fever (BEF) in Cattle. Nepalese Vet. Journal. 1-5.

Sellers, R. F. (1980) Weather, host and vectortheir interplay in the spread of insectborne animal virus diseases. J. Hyg. 85 (1): 65-102. https://doi.org/10.1017/ S0022172400027108

Sendow, I. (2013) Bovine Ephemeral Fever, Penyakit Hewan Menular yang Terkait dengan Perubahan Lingkungan. Wartazoa 23 (2) : 76-83

Sendow, I., Adjid, R.M.A., Saefulloh, M. (2017). Infeksi Virus Peste de Petits Ruminants (PPR) pada Kambing dan Domba di Indonesia. Jurnal Sain Veteriner 35 (2): 165-174

Shin, Y-K., Oem, J-K., Yoon, S., Hyun, B-H., Cho, I-S., Yoon, S-S. and Song, J-Y. (2009) Monitoring of Five Bovine Arboviral Diseases Transmitted by Arthropod Vectors in Korea Journal of Bacteriology and Virology. 39(4):353 - 362. DOI 10.4167/ jbv.2009.39.4. 353 
Shirakawa, H., Ishibashi, K. and Ogawa, T. (1994) A comparison of the epidemiology of bovine ephemeral fever in South Korea and southwestern Japan. Aust. Vet. J. 71(2): 50-52. DOI: 10.1111/j.1751-0813.1994.tb06153.x

Snowdon, W.A. (1970) Bovine ephemeral fever: the reaction of cattle to different strains of ephemeral fever virus and the antigenic comparison of two strains of virus. Aust. Vet. J. 46 (6):258-266. https://doi. org/10.1111/j.1751-0813.1970.tb15773.x

Soeharsono, Sudana, I.G., Unruh, D.H. and Malole, M. 1983. Dugaan letupan Penyakit Demam-Tiga-hari pada Sapi Ongole di Tuban dan Lamongan. Hemerazoa, 71(2): 127-133.

Song, G.C. and Kang, B.J. (1970) Development of vaccine and diagnostic methods for bovine ephemeral fever. NVRQS Annual Research Report 1970. 61-68

St George, T.D. (1988) Bovine Ephemeral Fever : A Review. Trop. Anim. Hlth. Prod. 20 (4): 194-202. DOI: 10.1007/BF02239980

St George, T.D. (2004) Bovine ephemeral fever. In: Coetzer JAW, Tustin RC (eds). Infectious Diseases of livestock. Oxford University Press, Oxford, 1183-98.

St. George T.D. (1994) Bovine ephemeral fever. In: Coetzer JAW, Thomson GR, Tustin $\mathrm{RC}$, eds. Infectious Diseases of Livestock with Special Reference to South Africa. Capetown, South Africa: Oxford University Press, Chapter 49, 553-562.

St George, T. D. and Standfast, H. A. (1988) Bovine ephemeral fever. In The Arboviruses: Epidemiology and Ecology, 2:71-86. Edited by T. P. Monath. Boca Raton: CRC Press.

Standfast, H.A., Dyce, A.L., St George, T.D., Muller, M.J., Doherty, R.L., Carley, J.G. and Filippich, C. (1984). Isolation of arboviruses from insects collected at Beatrice Hill, Northern Territory of Australia, 1974-1976. Australian Journal of Biological Sciences, 37(5/6):351-366. PMID:6152599

Stram, Y., Kuznetzova, L., Levin, A., Yadin, H. and Rubinstein-Giuni, M. (2005) A real-time
RT-quantative (q) PCR for the detection of bovine ephemeral fever virus. Journal of Virological Methods, 130 (1-2): 1-6. https:// doi.org/10.1016/j.jviromet.2005.05.024

Stram, Y., Kuznetzova, L., Levin, A., Yadin, H. and Rubinstein-giuni M. (2005) A real-time RT-quantative PCR for the detection of bovine ephemeral fever virus. J. Virol. Meth. 130 (1-2): 1-6. https://doi.org/10.1016/j. jviromet.2005.05.024

Strauss, J.H. and Stauss, S.G. (2008) Chapter 4 - Minus-Strand RNA Viruses. Viruses and Human Disease (Second Edition). 137-191 https://doi.org/10.1016/B978-0-12-3737410.50007-6

Sutherst, R.W. (2004) Global change and human vulnerability to vector-borne diseases. Clin. Microbiol. Rev. 17(1):136- 73. doi: [10.1128/CMR.17.1.136-173.2004

Suwito, W. and Nurini, S. (2009) Penyakit pada sapi di Puskeswan Godean tahun 2006-2008. Dalam: Sani Y, Natalia L, Brahmantiyo B, Puastuti W, Sartika T, Nurhayati, Anggraeni A, Matondang RH, Martindah E, Estuningsih SE, penyunting. Teknologi peternakan dan veteriner mendukung industrialisasi sistem pertanian untuk meningkatkan ketahanan pangan dan kesejahteraan peternak. Prosiding Seminar Nasional Teknologi Peternakan dan Veteriner. Bogor, 13-14 Agustus 2009. Bogor (Indonesia): Puslitbang Peternakan. 290-299.

Thabet, N.S., Ghazy, E.W., Nayel, M.A. and Abo-Elkhair, M. (2011) Molecular and biochemical studies on bovine ephemeral fever. Research Opinions in Animal dan Veterinary Sciences 1(5): 269-275.

Theodoridis, A., Giesecke, W. H. and Du Toit, I. J. (1973) Effects of Ephemeral Fever on Milk Production and Reproduction of Dairy Cattle. Onderstepoort J. vet. Res. 40 (3): 8392. PMID:4207531

Thomson, M. C. and Connor, S. J. (2000) Environmental information systems for the control of arthropod vectors of disease. Medical and Veterinary Entomology. 14 (3): 
227-244. https://doi.org/10.1046/j.13652915.2000.00250.x

Tian, F.G., Jiang, C.L., Zakrzewski, H. and Davis, S.S. (1987) A comparison of a Chinese and an Australian strain of bovine ephemeral fever virus. Aust. Vet. J. 64 (5):159-159. https://doi.org/10.1111/j.1751-0813.1987. tb09670.x

Tonbak, S., Berber, E., Yoruk, M.D., Azkur, A.K., Pestil, A. and Bulut, H. (2013) A LargeScale Outbreak of Bovine Ephemeral Fever in Turkey. J. Vet. Med. Sci. 75(11): 15111514. doi: 10.1292/jvms.13-0085

Trinidad, L., Blasdell, K.R., Joubert, D.A., Davis, S.S., Melville, L., Kirkland, P.D., Coulibaly, F., Holmes, E.C. and Walker, P.J. (2014) Evolution of Bovine Ephemeral Fever Virus in the Australian Episystem. Journal of Virology 88 (3): 1525-1535. doi:10.1128/ JVI.02797-13

Tuppuraunen, E.S.M. (2004) The detection of LSD virus in samples of experimentally infected cattle using different diagnostic techniques. Master Thesis, Veterinary Science, Veterinary Tropical Diseases, Faculty of Veterinary Science University of Pretoria.

Uren, M. (1989) Bovine ephemeral fever. Aust. Vet. J. 66 (8):233-236. https://doi. org/10.1111/j.1751-0813.1989.tb13577.x

Uren, M.F. and Murphy, G.M. (1985) Studies on the pathogenesis of bovine ephemeral fever in sentinel cattle. II. Haematological and biochemical data. Vet. Microbiol. 10(6): 505-15. https://doi.org/10.1016/03781135(85)90059-8

Uren, M.F., St George, T.D. and Zakrzewski, H. (1989) The effect of anti-inflammatory agents on the clinical expression of bovine ephemeral fever. Vet. Microbiol. 19 (2):99 111. DOI: 10.1016/0378-1135(89)90076-X

Uren, M.F., St. George, T.D. and Murphy, G.M. (1992) Studies on the pathogenesis of bovine ephemeral fever in experimental cattle. III. Virological and biochemical data. Vet Microbiol 30(4):297-307. https://doi. org/10.1016/0378-1135(92)90017-N
Venter, G. J., Hamblin, C. and Paweska, J. T. (2003) Determination of the oral susceptibility of South African livestock-associated biting midges, Culicoides species, to bovine ephemeral fever virus. Medical and Veterinary Entomology.17 (2): 133-137. DOI | 10.1046/j.1365-2915.2003.00414.x

Vorster, J. H. and Mapham, P.H. (2013) Bovine ephemeral fever. Livest Health Prod Rev $16: 5-8$

Walker, P.J. (2005) Bovine ephemeral fever in Australia and the world. Curr. Top. Microbiol. Immunol. 292:57-80. http:// dx.doi.org/10.1007/3-540-27485-5-4.

Walker, P.J. and Klement, E. (2015) Epidemiology and control of bovine ephemeral fever Vet. Res. 46 (124): 1-19 DOI 10.1186/s13567015-0262-4

Walker, P.J., Byrne, K.A., Cybinski, D.H., Doolan, D.L. and Wang, Y. (1991) Proteins of bovine ephemeral fever virus. J. Gen. Virol. 72 (pt 1): 67-74.DOI:10.1099/0022-1317-72-1-67

Wallace, D.B. and Viljoen, G.J. (2005) Immune responses to recombinants of the South African vaccine strain of lumpy skin disease virus generated by using thymidine kinase gene insertion. Vaccine 23(23): 3061-3067. https://doi.org/10.1016/j. vaccine. 2004.10 .006

Walthall, J.C. and Vanselow, B.A. (1986) A field trial of a bovine ephemeral fever vaccine. In: St. George TD, Kay BH, Blok J, eds. Proceedings of the Fourth Symposium on Arbovirus Research in Australia, 1986. Brisbane, Australia: CSIRO/QIMR, 316318.

Winoto, S. and Sjafarjanto, A. (2014) Kejadian penyakit bovine ephemeral fever (BEF) pada sapi potong peranakan limousin di Kecamatan Soko Kabupaten Tuban. https:// jurnalvitek.com/jv/article/download/8/10

Wongwatcharadumrong, R., Chaipoca, C. and Kishi, S. (1984) Preliminary report of neutralizing antibody examination in bovine ephemeral fever in the southern part of Thailand. Thai. J. Vet. Med. 14:23-30 
Yeruham, I., Van Ham, M., Stram, Y., Friedgut, O., Yadin, H., Mumcuoglu, K.Y. and Braverman, Y. (2010) Epidemiological Investigation of Bovine Ephemeral Fever Outbreaks in Israel. Veterinary Medicine International, 2010 (Article ID 290541) : 1-5 doi:10.4061/2010/290541

Young, P.L. and Spradbrow, P.B. (1985) Transmission of virus from serosal fluid and demonstration of antigen in neutrophils and mesothelial cells of cattle infected with bovine ephemeral fever virus. Vet. Microbiol. 10(3): 199-207. DOI: $10.1016 / 0378-1135(85) 90046-\mathrm{X}$

Zaghawa, A. (2006) Bovine ephemeral fever (Three day sickness). A Review with special reference to the Egyptian situation. Menoufia Vetrinary J. 4(1): 101-117
Zaghawa, A.A., Housawi, F., Al-Naeem, A., Elsify, A. and Hegazy, Y.M. (2017) Bovine ephemeral fever epidemics in Kingdom Saudi Arabia: clinical, epidemiological and molecular investigation. J. Infect. Dev. Ctries. 11(11):854-860. doi:10.3855/ jidc. 8201

Zheng, F., Lin, G., Zhou, J., Wang, G., Cao, X., Gong, X. and Qiu, C. (2011) A reversetranscription, loop-mediated isothermal amplification assay for detection of bovine ephemeral fever virus in the blood of infected cattle. J. Virol. Methods. 171(1): 306-309. DOI:10.1016/j. jviromet.2010.10.028 